\title{
The State, MNCs and Natural Resources in Latin America
}

\section{Carlos Fortin}

\section{The limitations of bargaining models of MNC-host country relations}

A good deal of the current discussion on the relationship between multinational corporations and the peripheral State in the area of natural resources ${ }^{1}$ is framed in terms of models of bargaining. Such models identify two actors-the MNC and the 'host country'-whose behaviour is assumed to be utilitymaximising and whose interests, while conflicting, are seen as not necessarily incompatible. They then proceed to ask questions such as, What are the possible joint-maximisation outcomes in the interaction? What is the bargaining strength of the actors? and How do different bargaining strategies affect the outcome? Two main strands within this approach can be identified: one, which has been labelled 'static', is based on game theory and the theory of bilateral monopoly (Moran, 1974 : 158ff ; Mikesell, 1971:40ff); another, which is dynamic and more influential, is discussed in this article.

The basic variables in the dynamic bargaining model of foreign investor-host country relations in natural resources are: the bargaining assets of both actors; their perceptions of goals and possibilities of achieving them; their knowledge of the substantive elements of the relationship-i.e. the operation of the extractive industry in question - and of the bargaining process itself; and the way in which all threepower, perspectives and knowledge-change in a more or less predictable manner.

Whether applied to the operation through time of a single concession, or to the various relationships between the host government and foreign investors, or to general trends in the terms of new concessions, the model suggests that at the beginning of the relationship it is the foreign investor who is in a position of strength through his control over capital, technology and markets; he is also keen to use his advantage in order to get maximum privileges in view of the risk involved in committing substantial capital to a venture that he perceives uncertain both in terms of its economic profitability and its political life expectancy. On the other hand, the host government's eagerness to put the country's natural

1 For purposes of the present discussion, 'natural resources' refers to petroleum, hard minerals and other non-renewable resources. riches to good use is matched only by its acute awareness of its inability to do so without the foreign investor. Hence the 75 -year concession, with no serious obligations for the investor. However, as soon as operations start-as soon as the prospective deposit is confirmed as economically valuable, oil starts to flow or minerals to surface, and profits begin to show-then the bargaining strength position is reversed and the perspectives change. It is now the investor, who has sunk his capital, who is more or less at the mercy of the host government: he can be taxed, subjected to regulations of various kinds and in the last resort expropriated. The risk has, furthermore, either disappeared or been considerably reduced, and the government begins to find the original terms of the concession excessive. It is at this point that the government will request and, if necessary, impose a revision of the terms. When next time round the same or another investor is called upon to expand the operation, or to extend it downstream into more processing, or to introduce new technology, the relative power positions and the corresponding perspectives are reversed again, only to swing back once more when the investment is sunk and profitable.

The process, however, is not simply cyclical. For one thing, the advantages of the international firms generally have a tendency to be eroded through time, as technology becomes standardised and disseminated, patents expire, capital markets develop and become more competitive-including 'aid' markets -and production and marketing know-how becomes available on a for-hire basis. For another, each host government undergoes a cumulative learning process on the basis of its own experience in successive negotiations, of diffusion of relevant knowledge generally and, perhaps less commonly, of sharing bargaining experience with other host governments. The government becomes increasingly capable of handling the foreign investor and indeed the industry itself, and its bargaining strength is commensurately higher. Finally, cumulative trends affect the perspectives of the host government in the direction of emphasising the need to change to its advantage the terms of the relationship with the foreign investor: the inevitable growth of contact between the foreign enclave and the economy and the legal system of the country makes for difficulties and tensions that require adjustment; fiscal budgetary needs associated with development call for an evergrowing claim on the proceeds of the foreign 
operation; and the sense of dependency that the latter creates fosters feelings of nationalism.

So, the model predicts that the cyclical and reciprocal pattern of strength and weakness for the foreign investor and the host government will be reflected in the changing terms of their relationship through time, but within an overall cumulative trend for the host government to increase its share of benefit from the relationship. (Moran, 1974: 157-69; Vernon, 1967: 81-90, 1971; Mikesell, 1971: 35ff; Smith and Wells, 1975)

The preceding explanation is valuable in that it helps demystify the notion of the sanctity of the concession contracts: by emphasising the power context in which they are initially entered into and in which they operate, it exposes their fallacious claim to moral and legal immutability. This assessment is especially significant considering that the main exponents of this approach are committed supporters of capitalism and, on the whole, of the multinational enterprise as a vehicle of progress and development.

Further, it goes some way in helping to understand the changes that are taking place in the international political economy of natural resources in the 1970s. Its weakness lies in its failure to relate the abstract power and learning processes it describes to the concrete contemporary development of the world capitalist system and its implications for the natural resource industries. It does not place the relations between foreign investors and host governments within the context of the changing relations between the centre and the periphery of the capitalist system, and their 'internal' expression in the latter. Thus, the objectives and interests of the foreign investors appear unrelated to those of the larger system of which they are a part, as well as to the particular national objectives and interests of their individual home economies and governments. Conversely, it assumes-qua model, i.e. as far as the generalisable and predictable behaviour of the actors is concernedthat the host countries are homogeneous actors trying to maximise through time the benefits to the local economy deriving from foreign investment, and progressively achieving this goal through a strengthening of their bargaining power and their knowledge. Such an assumption, while rightly pointing to the bargaining assets available to, and the learning process undergone by, the governmental decisionmakers involved as significant variables, impoverishes the analysis by excluding systematic reference to the internal structure and development in those countries; the changes in the economic infrastructure, in the class structure and in the political forces of the periphery of capitalism as they relate to the development of the capitalist system world-wide. ${ }^{2}$
It can, however, be argued that the basic elements for understanding the contemporary international political economy of natural resources in terms of the emergence of nationalism in the underdeveloped world and the responses of international capital are given by understanding the structural changes that have taken place both in the centre and in the periphery of the world capitalist system after World War II. To these we shall now turn our attention.

\section{A historico-structural approach}

It is of course well known that the world capitalist system experienced a major restructuring after the Second World War, in response both to tendencies that had appeared before the conflict and to developments resulting from it. Several of those major changes have a direct impact on the international political economy of natural resources.

To begin with, the trend towards increased dependence of the industrialised world on industrial raw materials from the underdeveloped countries is being countered by another trend inherent in the capitalist mode of production: that towards the development of the productive forces and technical progress which was further accelerated by the requirements of the war economy. This has resulted in a tendency for the raw material content of the finished product of the industrialised economies to decline, as the technological content tends to increase; it has also made possible a massive expansion in the use of synthetic substitutes, most notably plastics, thus further reducing the need for natural resources generally (in relative terms). Technical progress has, moreover, contributed to reducing the need for industrial raw materials from the underdeveloped world by increasing the availability of them in the developed countries. Advances in the techniques of exploitation of lowgrade ores have transformed hitherto neglected areas of the industrialised world into economically viable conventional mineral deposits, as is the case with copper reserves in the United States, Canada and Australia, for instance. Unconventional sources of minerals and metals are being explored, such as seabed manganese nodules, that appear to be a potentially important source of nickel, among other materials, and high-alumina clays, that can replace

\footnotetext{
2 Not that the internal structures of the host countries are ignored; it is, though, that they seem to be regarded as unsusceptible of theoretical treatment, i.e. of systematic inclusion in the model in a way that will allow some predictability of behaviour. The references to these factors in the best analyses are, therefore, more or less casual, as in Vernon 1967: 193-201, or explicitly relegated to the empirical description of specific cases, as in Moran (1974: 170). To include these elements in a theoretically meaningful way would require adopting some sort of general theory of the
origins, dynamics and development of modern capitalist society. This fundamental epistemological choice is an intellectually risky step that most non-Marxist analysts of capitalism do not seem prepared to take.
} 
bauxite as a source of aluminium and are abundant in the United States. Significant improvement has also been achieved in the recovery and re-cycling of used metal; the great bulk of the potentially reusable metal of the world is, of course, in the industrialised countries. The general trend has been reinforced by the emergence of the United States as the centre of the capitalist system. The US is comparatively more self-sufficient in natural resources than the European countries, and although its net requirements of natural resource imports seem to have grown as a percentage of domestic consumption, for a number of materials the opposite is actually the case.

This is not meant to suggest that the developed world no longer needs primary products from Africa, Asia and Latin America; a substantial part of the industrial raw material requirements of the developed economies still come from the so called Third World, and in one crucial area - that of energy-the degree of dependency has, if anything, increased in recent years. ${ }^{3}$ The point is that we are assuming that the concrete behaviour of various agents in the capitalist system (firms, governments) is determined in the last analysis by the logic of the system as a whole, and that the latter will express itself not in spite of, but rather, through the contradictions, counter-tendencies and circumstantial determinations that the process will exhibit at any given point in time. The relative reduction of the dependence of the industrialised world as a whole on underdeveloped countries' raw materials points to a trend in the logic of operation of capitalism in the period under consideration and is therefore a necessary part of the explanation of concrete empirical phenomena which does not exclude major variations in the degree of self-sufficiency of various developed economies (Japan, for instance, is singularly lacking in most industrial raw materials), and periods of intense competition for privileged access among governments and firms.

\section{TABLE 1}

United States: Expenditure in New Plant and Equipment in the Mining and the Communication Industries as Percentages of Total Expenditure (five-yearly averages)

\begin{tabular}{|c|c|c|c|c|}
\hline $1950-54$ & $1955-59$ & $1960-64$ & $1965-69$ & $1970-74$ \\
\hline Mining 4.5 & 4.4 & 3.3 & 2.5 & 2.6 \\
\hline \multicolumn{5}{|c|}{ Communications } \\
\hline 6.0 & 8.0 & 9.6 & 10.0 & 12.9 \\
\hline
\end{tabular}

3 Oil is, however, in many respects an exceptional case, because of the distribution of world reserves, the absence of substitutes, its perishable character and the fact that many of the technological innovations that save in other materials require more energy than traditional technologies or are
themselves based on petro-chemical derivates; even in oil, themselves based on petro-chemical derivates; even in oil,
of course, the search is already on for new sources and substitutes, and there is little doubt of the likelihood of important oil-saving technological innovations in the long-run.
One of its expressions is a shift in the locus of capital accumulation away from the extractive industries and towards the technology intensive sectors of manufacturing and service industries, a point illustrated in Table $I$ which shows the relative decrease in US domestic expenditure in new plant and equipment in the mining industry in the period 1950-74, and compares it with the spectacular increase of expenditure in the communications industry for the same period. A parallel decrease is shown by available figures on capital expenditure in mining and smelting by US firms in the underdeveloped countries. ${ }^{4}$ This reflects not only the wellknown general shift of US foreign investment from mining and smelting towards manufactures, but also the decrease in US investment in mining in underdeveloped countries as compared to investment in mining in other developed countries (Tables 2 \& 3). For capitalism as a whole, therefore, the mining and smelting industries in the underdeveloped world have lost their primary interests as outlets for capital accumulation, while retaining importance as physical sources of industrial raw materials. This points to possible conflicts between central governments, interested primarily in access to supplies, and individual capitalists, interested in a continuous flow of profits.

\section{TABLE 2}

Value of United States Direct Investment Abroad in Mining and Smelting

(percentages, selected years)

195019551960196519701974

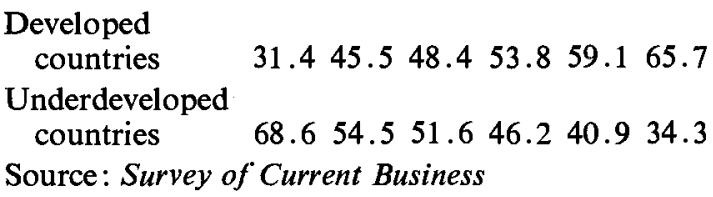

TABLE 3

US Direct Investment Abroad: Distribution of Net Capital Outflows and Undistributed Subsidiary Earnings in Mining and Smelting (percentages, ten-yearly averages) 1950-59 1960-69 (1970-74)

\begin{tabular}{|c|c|c|c|}
\hline Developed countries & 50.6 & 72.3 & $(90.1)$ \\
\hline $\begin{array}{l}\text { Underdeveloped } \\
\text { countries }\end{array}$ & 49.4 & 27.7 & $(9.9)$ \\
\hline
\end{tabular}

4 The time series of percentages of US net capital outflows plus undistributed subsidiary earnings corresponding to mining and smelting in underdeveloped countries for the period 1950-74 shows a declining trend as measured by a least square regression line. The regression constant is 6.8709 and the regression coefficient is -0.2860 . The original data was obtained from the Survey of Current Business. 
The development of contemporary capitalism has also created the conditions for a redefinition of centre-periphery relations in natural resources that can satisfy the individual capitalist. As the contemporary agent of world capitalist expansion is the vertically integrated multinational corporation, the individual capitalist has acquired the ability to transfer the locus of profits from one stage of the productive process to another, and to recapture the capacity to derive monopoly rents by concentrating on the stages where it retains monopoly control over technology. In addition, new forms of surplus extraction have been developed that can satisfy nationalistic feelings in the underdeveloped world without effecting any significant changes in the international sharing of surpluses or in the effective control over the industry internationally. The most important of these are:

1. Joint ventures with the host State, with varying proportions of equity distribution. Irrespective of the percentage owned by the host State, such joint ventures often incorporate the feature that the partner in charge of the management of the operation, as well as the marketing of the product, is the foreign corporation. The distribution of profits on the basis of the shared equity is often offset by the privileged tax and duty regime accorded the joint venture, where the foreign partner would normally also have special rights in terms of repatriation of profits and income tax on distributed dividends. ${ }^{5}$

2. The emergence of service contracts with foreign companies, even in the absence of any equity participation. These may refer to the management of the operation, or the procuring of inputs from abroad, or the international sales of the product, or the provision of technology, engineering, etc., or combinations of these. Through these arrangements the MNC can retain control over the industry and secure for itself a flow of surplus which is not necessarily less than what its profits would have been had it been the owner of the operation. In fact, it is becoming apparent that these are the preferred formats for the operation of MNCs in the field of natural resources in the underdeveloped world. (Proceedings of the American Society for International Law, 1973: 227-45; Smith \& Wells, 1975).

3. Packages of finance and technology for new investment linked to sales of the future products of the venture at privileged prices. This is a particularly good solution for MNCs that are integrated downstream, such as US oil companies. Agreements for the privileged supply of products to former

5 There is wealth of literature on joint ventures in underdeveloped countries. See W. Friedmann et. al. 1971 and Wells Jnr., 1970. owners also feature prominently in contemporary nationalisations of natural resource industries.

\section{The State and nationalism in natural resources}

This analysis suggests that the underlying trends of the operation and expansion of capitalism after the Second World War appear to favour the emergence of forms of nationalism in natural resources in the underdeveloped world. This is not to imply that conflict will not take place whenever such nationalism asserts itself, as those MNCs involved, whose activity may be directly curtailed as a result, will no doubt derive little comfort from learning that the process is in line with deeper trends in the development of capitalism, and will on the contrary fight against nationalistic attempts. As suggested above, however, the basic trends help understand and predict the reaction of capitalism as a whole and of the governments of the central countries, as representatives of national capitalist classes. Equally crucial for the assessment of the conflicts that may occur and their likely resolution is the real meaning of nationalist resource policies in terms of the politico-economic projects and structures of political and social domination with which they are associated.

The most general framework in which to approach the latter is by looking at the reasons for the emergence of a 'natural resource ideology' throughout the Third World in the 1960s and 1970s. This has expressed itself in international declarations such as the 1962 UN General Assembly Resolution 1803 on Permanent Sovereignty over Natural Resources (proposed by Chile and supported by most developing countries at the time) and the initiatives of the Group of Non-Aligned Countries that resulted in the Declaration and Programme of Action on the New International Economic Order (UN General Assembly Resolutions 3201 (S-VI) and 3202 (S-VI), May 1, 1974) and the Charter of Economic Rights and Duties of States (UN General Assembly Resolution 3281 (XXIX), December 12, 1974). A curious feature of this phenomenon is the fact that it cuts across enormous differences in the economic, social and political structures of the countries of Asia, Africa and Latin America, in the political projects advanced by their ruling sectors and in the political alignment of their governments in the world arena. Aside from the fact that at least some of this unanimity is explainable in terms of the ineffectualness of the initiatives so far, other factors are also in operation. The development of the productive forces in the periphery of world capitalism and their corresponding effects in the level of the class struggle and in the political superstructure have given impulse to the emergence of anti-system movements that represent truly nationalistic projects and that cannot be completely ignored even in contexts in which the 
domination of groups co-opted by international capitalism is well established. Some of those sectors were constituted and/or strengthened in the struggle for colonial independence in Africa and Asia in the 1960s. From the viewpoint of the dominant classes, particularly in countries where natural resource industries represent a substantial sector of the economy, the needs of capital accumulation call for an increasing share of the surplus generated by the industries to be captured by the State; this process is not contradictory, indeed it is functional, with the insertion of the peripheral economy in the international circuit of capital through direct investment in the manufacturing industries. The role of the State in such cases may range from that of simply providing the essential infrastructure and supporting local capital that performs a subsidiary role to the dynamic expansion of the manufacturing MNCs, to a more direct participation in the process of capital accumulation, including the area of natural resources. The experience of the OPEC countries has no doubt strengthened the resolve of dominant sectors in the periphery whose purpose is not to break ties with world capitalism but rather to increase their share in the distribution of surplus coming from natural resources among other things to tighten the integration of their economies in world capitalism through foreign investment in other areas. A whole range of possibilities thus appear as concerns the policies of peripheral States towards natural resource MNCs, from those that are designed only marginally to alter the international sharing of surplus-irrespective of the rhetoric with which they may be presented-to truly revolutionary attempts to break away from dependency in natural resources.

Any concrete analysis of the relationship between the State in Latin America and the natural resource MNCs must therefore incorporate an examination of the nature of the State in the various countries considered, with a view to illuminating its concrete class character and the societal project that the dominant sectors are putting forward. More specifically, the following elements may help to clarify the real significance of various government policies for natural resource MNCs and the limits that such policies have:

1. Role, actual and/or potential, played by natural resource industries in the generation of surplus value that can be profitably capitalised. How dynamic is or can be the natural resource sector in the process of capital accumulation? Indicators would be the export $v$. domestic importance of the natural resource industries and their exchange revenue earning importance; the size of resource reserves; the linkages with the local economy; and the possibilities of downstream integration at the national level.
2. Degree of differentiation of the productive structure and the corresponding differentiation of the class structure. What is the nature of the dominant classes? Are they agrarian oligarchies, financial, commercial or industrial bourgeoisies, or combinations thereof? What is the degree of autonomy of State bureaucracies? Conversely, what is the class composition of the popular sectors, and what their political expression(s)?

3. What is the nature of the societal project of the dominant class? Is it an attempt to break away from dependency ties with the world capitalist system, or to redefine a convenient form of insertion in it along the lines offered by the contemporary process of internationalisation of capital? What is the role assigned to the State in the process of accumulation?

The following paragraphs will offer a very tentative first approximation to applying this type of analysis to the question of the relationship between the State in Latin America and the MNCs in natural resources.

\section{Some Latin American illustrations}

Many of the major initiatives to redefine the relationship between the State and natural resource MNCs in Latin America in the 1960s originated in countries undergoing a process of industrialisation essentially activated by direct foreign investment but also with a substantial element of local capital accumulation and the consequent emergence of a national industrial capitalist sector, linked to the foreign sector; with a State with a certain degree of autonomy, given by the presence of a strong bureaucracy that can in some instances arbitrate among the various fractions of the dominant class; and with popular movements with a strong nationalistic ideological content. Given that the basic politico-economic project of the dominant sectors was one of reinsertion in the world capitalist system, rather than of adopting a non-capitalist path, the extent of the redefinition of the relationship with natural resource MNCs becomes a question of balancing the need to increase the local share of surplus and satisfy nationalistic sentiment with the need not to break away from the international capital circuit. The results range all the way from purely formal changes with minimal effect on either surplus sharing or control, to somewhat deeper restructurings.

\section{Mexico, 1961}

An early instance in the decade was the Mexican mining law of 1961. This essentially restricts the granting of mining concessions to companies the majority of whose capital is in the hands of Mexicans. While no provision was included to alter the ownership status of current concessions (which could 
have continued in foreign hands for up to 25 years after the law) extraordinary tax privileges were granted to Mexican controlled companies, amounting to a reduction of 50 per cent of the net federal portion of production and export taxes, and the right to request further reductions under special agreements. In view of the amount of the tax concessions most foreign-owned companies proceeded quickly to negotiate sales of majority interests to Mexican investors. By 1965, control of all major companies (except two sulphur companies) had been acquired by Mexicans (Wright, 1971: 139-40)

Several elements are worth noting in this instance. First, in 1961 the Mexican mining industry was producing for the domestic market to a much larger extent than usual in Latin America. In fact, demands for Mexicanisation grew apace with the growth of domestic demand as industrialisation began in the late 1940s. By the end of the 1950s between one-fifth and one-fourth of production was being consumed by Mexican industry; it was the Mexican large industrialist sector that pressed for Mexicanisation in order both to have a share in the growth of the mineral industry and, most importantly, to be able to integrate upstream (Brothers, 1970: 16). While one manifest aim of the measure was to attract many small Mexican investors into the industry, as one observer notes "finding Mexican buyers for their shares (was) extremely difficult for foreign companies trying to comply with the Mexicanisation requirements, and with very few exceptions, control of the important mining companies has passed from a large number of foreign investors into the hands of a small group of Mexican owners" (Wright, 1971:140) The true meaning of the new regime was, therefore, to transfer surpluses to the local large capitalists, not at the expense of the MNCs but rather of the State. "Earnings on the minority interests received by the foreign companies appear to be at least as large as those realised before Mexicanisation, reflecting not only tax benefits but also various fees charged the new joint ventures under management and technical assistance contracts with the former parent companies. Moreover, the funds received from Mexican investors have generally been invested in highly profitable industrial enterprises . . . presumably considerable dividends to the new domestic entrants into mining have been realised by integrating their industrial activities with raw material sources" (Brothers, 1970: 17). The mining law of February 1976 has not substantially changed the situation, which is one in which mining MNCs can operate without significant restrictions and with a highly privileged tax, profit-remittance and autonomy regime, pro- vided a part of the surplus generated is transferred to the local capitalist sector (LAER, 1976).

Not surprisingly, Industrial Minera Mexicanaformerly American Smelting and Refining Company -announced, after the law became effective, that it would invest $\$ 300 \mathrm{~m}$ in expanding its silver, copper, zinc and coal operations in Mexico (LAER, 1976).

\section{Chile, 1967}

The other major attempt at redefining the relationship between natural resource MNCs and the State in Latin America in the 1960s was the 'Chileanisation' of the copper industry carried out by the Frei Government in Chile in 1967-69. ${ }^{6}$ The context here was, of course, entirely different from the Mexican experience. In 1964, when negotiations with the American MNCs started, the Chilean economy was stagnating, after the exhaustion of the import substituting process had led to a halt in investments both by local capital and, despite the generous terms offered by the conservative Alessandri administration, also of foreign investment. In particular, the US copper companies refused to embark on any major new projects as they felt their tax regime was excessively onerous. Copper, on the other hand, was a crucial sector for capital accumulation; 95 per cent of production was exported, generating about 75 per cent of foreign exchange. The Frei Government wanted capitalist development for Chile based on the modernisation of agriculture and the transfer of surpluses from agriculture to industry; strong participation of the State both in creating the conditions for industrial capitalist accumulation and in the accumulation process in the basic industries; and attracting private foreign investment particularly in the manufacturing sector, as well as massive US aid and credit under the Alliance for Progress. Further, it had redistributive aims, in line with the fact that the support for Frei's Christian Democratic Party included important sectors of the peasantry, the urban proletariat and the 'marginal' sectors; to this one must add the presence of a strong Marxist opposition pressing for both redistributive and nationalistic measures. Both the project, therefore, and the ideological context required an effective increase in the State share of copper revenue.

This, however, was to be accomplished not so much by means of increasing the share of the State in the existing levels of revenue but rather by means of a major investment programme that would increase

6 The best comprehensive discussion of the Frei copper policies in English is Moran, (1974), which further includes a useful bibliography. 
production and revenue substantially over a fiveyear period. The presence of American MNCs was regarded as essential to the securing of finance for the programme and to its implementation, as was the necessity to offer adequate incentives for their continuing involvement. The solution was to set up joint ventures by means of the purchase by the State of a 51 per cent interest in the existing operations, ${ }^{7}$ and to grant the new joint companies a very favourable tax regime. that would compensate the American MNCs for their divestment of a majority of the equity. The American companies would, furthermore, be in charge of the management of the operations, the procuring of imported inputs and the sales of copper in the world market, although the State would retain a supervisory role through its majority presence on the Boards, and would gradually increase its participation in the operational functions. In practice, therefore, the American MNCs retained effective control over the industry, and their share of the surplus remained basically unaltered in relative terms, while in absolute terms (due to a large increase in the world price of copper in 1967-69) it increased dramatically. This, in turn, led to a resurgence of nationalistic feeling in various sectors, including within the government party, which in the last months of the Frei Government pressed for a further redistribution of profits in favour of the State (through a preferential dividend in its favour when the price exceeds a certain level). If we relate this experience to some of the concepts suggested above and compare it with the Mexican case, the differences become apparent. In the Chilean case, the attempt was aimed at gaining for the State a quantum of participation (more apparent than real at the beginning but with a potential for growth) in an industry of crucial importance for the process of capital accumulation in the economy generally, and at increasing its share of the surpluses through an acceleration of that process in the industry (as well as satisfying nationalistic aspirations among popular sectors both in the government party and in the opposition). All this without antagonising-in fact to a large extent at the request of-the American MNCs who would remain crucial actors in the process for some time to come. Full-scale nationalisation of the copper industry by the Allende Government in 1971 impeded, of course, the consolidation of this particular form of restructuring of State-MNC relations.

\section{The 1970s}

This model of interlocking relations between the State and MNCs in natural resource industries has

7 For an analysis of the form of the jcint venture arrangements, see Novoa 1972 chas. 1-9. become the prevailing one in the 1970s in those Latin American countries whose dominant sectors are bent on introducing a kind of dependent capitalist model of development. The forms this interlocking takes and the extent of actual State participation in the control and the surplus absorption vary. When, in Venezuela, the political project of the dominant sectors includes an element of popular mobilisation in a context of democratic politics, and where mineral resources constitute by far the most crucial and dynamic sector for capital accumulation, the policy is one of nationalisation, aimed at satisfying nationalistic sentiments and at increasing in real terms both State control and surplus extraction. However, in the case of the oil industry both concrete technical limitations in the ability to operate and expand the industry and to market the product, and the more general limits imposed by the need to remain in the international circuit of capital call for service agreements with the MNCs, whereby marketing of the oil is in the hands of the former owners (Exxon. Shell and Gulf); they furthermore provide technology to the nationalised companies, for which they are paid a flat fee per barrel of production. The compensation bonds are redeemable only in oil; the nationalisation law also allows for the creation of joint ventures, both in new and in existing operations, a provision that was bitterly fought against by the united opposition in Congress (LAER, 1976A). The regime of the nationalised iron industry is essentially similar to that of oil in these respects. In the case of the military authoritarian regimes, the approach towards MNCs in natural resources varies according to the political project of the power bloc, and in particular, in terms of the role assigned to the State in the process of capital accumulation. Brazil, the most consolidated of such regimes and whose hegemonic power bloc includes what has been called a 'State bourgeoisie' (Cardoso, 1975) seems to be a case in which the State will retain a significant degree of participation, and in some cases, control over natural resource industries. Thus, the normal format offered to foreign investors in minerals is that of joint ventures with State majority participation (Business Latin America, 1976: 366). In the case of oil, while exploration has been opened to foreign concerns, the draft contracts offered seem to safeguard the formal ownership of Petrobras over the fields and installations, while allowing for the signing of service contracts and the existence of production-sharing along lines similar to the Indonesian oil contracts (LAER, 1976B: 76).

At the other extreme, the Chilean military regime, whose view of development involves a much more secondary role for the State, has apparently re- 
verted to an open door policy for new ventures in copper, and has also opened oil exploration (until 1974 a State monopoly) to MNCs. This may well simply express the temporary predominance within the dominant sectors of the thinking of the Chicago school of economics, and may conceivably be reversed towards a more assertive role for the State in the process of capital accumulation when the limitations of the present economic project became intolerable. Significantly, the military have maintained the nationalisation of the existing large scale copper industry effected by Allende, although they have paid substantial compensation to the former owners (Fortin, 1975: 23-29).

A word is needed about the Allende experience of natural resource MNCs. The Unidad Popular model entailed a break with the American MNCs within an attempt to introduce structural changes in a socialist direction. Thus, copper was nationalised without compensation; control over both production, sales and purchases of imported inputs and over surpluses was assumed in full. ${ }^{8}$

The American MNCs embarked thereupon on an international offensive of legal and commercial sabotage, but one that was largely ineffective in disrupting the production or marketing of Chilean copper. It is difficult, of course, to assess the degree of success of the companies' offensive independently from the effects of the US government's blockade of the Chilean economy and its 'destabilisation' action, which were instrumental in determining the overthrow of Allende. It is now clear, though, that the decision of the Nixon administration to prevent the success of the Allende experiment in Chile by whatever means necessary was adopted independently of the conflict between Allende and the US copper companies, such that a solution to the latter would probably not have altered the basic resolve of the US government to work for the overthrow of the Popular Unity government. (United States Senate, 1976) In a number of respects, furthermore, the Chilean case was unique, in that it was always clear that the industry did not require the presence of the American MNCs either for the operation of the mines, or for marketing the copper. Even so, the policy of the Allende government was one of regarding the copper sector as the generator of surpluses that would finance the rest of the experiment; therefore the line taken was a cautious one, in which no dramatic changes were introduced either in the way in which the operation was run or in its system of external relations: the marketing arrangements under the nationalised regime remained essentially the same

8 For a general discussion of the nationalisation of copper by the Allende Government, see Novoa, (1972). On the international aspect $r$, C. Fortin, forthcoming. as when the American MNCs acted as sales agents. New ventures were invited internationally, both in copper and in other natural resources, but with arrangements that did not involve direct foreign investment or foreign control; the preferred arrangement was the kind that linked finance for a project to the future sales of the product in normal commercial terms. Despite the bad publicity that the expropriated American copper MNCs were able to create for the Allende government, capitalists in both Western Europe and Japan-and indeed, to some extent in the United States - were prepared to come to Chile and invest under the terms offered by the Allende government.

The Allende experience with the American copper companies shows, therefore, that at least under certain assumptions regarding ability to operate the industry, a peripheral government can effect a break with natural resource MNCs without disrupting the industry concerned. The distinguishing feature here was, of course, the nature of the political project for Chile that Unidad Popular was trying to implement. And it is also the nature of that project-more than the conflict with Anaconda and Kennecott-that explains the ultimate destruction of the experiment by the combined forces of internal reaction and US intervention.

\section{References}

Brothers, D. S., 1970, 'Mexican Policy Towards Foreign Investment', Harvard Development Adisory Service

Business Latin America, 1976, 'Brazilian Mining Sector appears capable of sustaining growth pace', November 17

Cardoso, F. E., 1975, Autoritarismo e Democratizacao, Paz e Terra, Rio de Janeiro

Fortin, C., 1975, 'Compensating the Multinationals: Chile and the United States Copper Companies', IDS Bulletin Vol 7 No 1

Friedman, W. et al, 1971, Joint International Business Ventures in Developing Countries: Case Studies and Analysis of Recent Trends, Columbia University Press, New York

Fortin, C., forthcoming, 'The Nationalisation of Copper in Chile and its International Dynamics', in S. Sideri and B. Evers (eds)., Chile: Structural Change in a Dependent Economy, Nijhoff, The Hague

Latin America Economic Report, 1976, 'Weak Mining Law in Mexico', Vol IV No. 18, February 20

1976A, 'Successful six months for Venezuelan oil industry', Vol IV No. 32, August 13. 
1976B, 'Questions remain on Brazilian oil contracts', Vol X No 19, May 14

Mikesell, R. F. (ed.), 1971, Foreign Investment in the Petroleum and Mineral Industries: Case Studies in Investor-Host Country Relations, Johns Hopkins Press, Baltimore

Moran, Theodore H., 1974, Multinational Corporations and the Politics of Dependence: Copper in Chile, Princeton University Press, Princeton

Novoa, E., 1972, La batalla por el cobre, Editorial Quimantu, Santiago

Proceedings of the American Society for International Law, 1973, 'Mining the Resources of the Third World: from Concession Agreements to Service Contracts', November

Smith, N. D., and L. T. Wells Jr., 1975, Negotiating Third World Mineral Agreements: Promises as Prologue, Ballinger Press, Cambridge (Mass.)
United States Senate, 1976, Hearings before the Select Committee to Study Governmental Operations with Respect to Intelligence Activities, Vol. 7: Covert Action, US Government Printing Office, Washington DC

Vernon, R., 1967, 'Long-Run Trends in Concession Contracts', Proceedings of the American Society for International Law, April

1971, Sovereignty at Bay, Longmans, London.

Wells, L. T. Jr., 1970, 'Foreign Investments in Joint Ventures: Some Effects of Government Policies in Less Developed Countries', Harvard Center for International Affairs, Economic Development Report No. 167

Wright, H. K., 1971, Foreign Enterprise in Mexico: Laws and Policies, University of North Carolina Press, Chapel Hill 